\title{
Nilai-Nilai Spritualitas dan Harmoni Beragama dalam Wirid Harian Kitab Al-Aurad Al-Nurāniyyah
}

\author{
Abdul Fadhil \\ Universitas Negeri Jakarta \\ e-mail: abdulfadhil21@yahoo.co.id
}

Naskah diterima: 16 Juli 2018, direvisi: 28 Juli 2018; disetujui: 30 Juli 2018

\begin{abstract}
This research is based on religious issues that are stuck to the practice of normative zhahiriyah. Whereas the religious perfection lies precisely in the balance in practicing the religious zhahiriyah and bathiniyyah. In the religious teachings that bathiniyyah can actually grow and develop religious spirituality. Wirid al-Aurād alNürāniyyah taught by tariqat al-Shäziliyyah containing readings is assumed to foster spiriualitas, harmony of religious behavior, not monolithic and tolerant. For this reason this study aims to describe and analyze the religious arguments about wirid. Then describe and analyze the texts, meanings, and interpretations of wirid al-Aurād al-Nürāniyyah. Finally, analyze the relevance of such wirid practice in developing religious spirituality. This research uses qualitative research approach with descriptive research method and literature study. Descriptive method and literature study is used to describe the study of tasawuf and wirid in religious perspective. Then describes the data concerning wirid al-Aurād al-Nürāniyyah, translating, and interpreting the meaning of wirid readings, and analyzing their relevance to the development of religious spirituality. The results showed that the daily wird of al-Aurād al-Nürāniyyah readings such as al-Fātiḥah, al-Wāqi'ah, shalawat, tahlil, tahmid, etc. as tariqat al-Shäziliyyah founder contained the meaning meaningful and relevant in developing religious spirituality. Wirid also as one effort in shaping the character of Islamic spirituality (Sufism). The wird that includes some form of remembrance and prayer contains an invitation to create harmony of life, pray for salvation and prosperity for all humanity regardless of religion and religious school.
\end{abstract}

Keywords: Wirid, Tariqat, Religious spirituality.

\begin{abstract}
Abstrak
Penelitian ini dilatarbelakangi oleh permasalahan keagamaan yang terjebak kepada pengamalan zhahiriyah yang bersifat normatif. Akan tetapi, kesempurnaan beragama justru terletak pada keseimbangan dalam mengamalkan keberagamaan yang zhahiriyah dan bathiniyyah. Di dalam ajaran agama yang bathiniyyah justru dapat menumbuhkan dan mengembangkan spiritualitas keberagamaan. Wirid alAurād al-Nürāniyyah yang diajarkan oleh thariqat al-Shāziliyyah. Di dalamnya terdapat bacaan-bacaan yang diasumsikan dapat menumbuhkan spiriualitas, keharmonisan perilaku keagamaan, tidak monolitik dan toleran. Untuk itu, penelitian ini bertujuan untuk mendeskripsikan dan menganalisis dalil-dalil keagamaan tentang wirid. Kemudian mendeskripsikan dan menganalisis teks, arti, dan interpretasi wirid al-Aurād al-Nūrāniyyah. Kemudian, menganalisis relevansi pengamalan wirid tersebut dalam mengembangkan spiritualitas keberagamaan. Penelitian ini menggunakan pendekatan penelitian kualitatif dengan metode
\end{abstract}


penelitian deskriptif dan studi literatur. Metode deskriptif dan studi literatur digunakan untuk mendeskripsikan kajian tasawuf dan wirid dalam perspektif keagamaan. Kemudian mendeskripsikan data-data menyangkut wirid al-Aurād alNūrāniyyah, menerjemahkan, dan menginterpretasikan makna terhadap bacaanbacaan wirid, serta menganalisis relevansinya terhadap pengembangan spiritualitas keberagamaan. Hasil penelitian menunjukkan bahwa wirid harian al-Aurād alNūrāniyyah bacaan-bacaannya seperti surat al-Fātiḥah, surat al-Wāqi'ah, shalawat, tahlil, tahmid, dan lain sebagainya seperti yang diajarkan oleh pendiri thariqat alShāziliyyah, mengandung makna yang berarti dan relevan dalam mengembangkan spiritualitas keberagamaan. Wirid juga sebagai salah satu upaya dalam membentuk karakter spiritualitas Islam (tasawuf). Wirid yang mencakup beberapa bentuk zikir dan doa tersebut berisikan ajakan untuk menciptakan harmoni kehidupan, mendoakan keselamatan dan kesejahteraan bagi sesama umat manusia tanpa memandang agama dan mazhab keagamaan.

Kata kunci: wirid, thariqat, spiritualitas keberagamaan.

\section{Pendahuluan}

Spiritualitas berasal dari kata spirit yang bermakna jiwa. Spirit dalam perspektif Islam biasanya disebut dengan rūh. Spirit dimaknai sebagai jiwa halus yang berasal dari Tuhan yang ditiupkan ke dalam diri manusia. Oleh karena berasal dari Tuhan, maka hanya ruh saja yang mampu berhubungan dan menyingkap tentang kebenaran yang berasal dari Tuhan (al-haqiqah). Dengan demikian, adanya ruh membuat manusia menjadi manusia yang bertuhan. Hanya manusialah yang mampu merasakan dan meyakini eksistensi dan keberadaan-Nya pada setiap fenomena di alam semesta ini.

Ruh (spirit) itu di dalam diri manusia berpotensi untuk untuk membentuk karakter yang baik dan terpuji, karena ruh bersifat suci yang merupakan karunia Tuhan yang berasal dari pancaran zat-Nya. Ruh tersebut bersemayam di dalam hati (qalb) manusia, sehingga dari hati inilah terpancar kecerdasan, keinginan, kemampuan, dan perasaan hasil dari pancaran cahaya kebaikan Tuhan. Ketika hati tersebut mendapatkan pancaran Tuhan, maka hati itu disebut dengan hati nurāni (hati yang tercahayai). Oleh karena itu, hati nurani pada diri manusia berpotensi untuk mengenal yang baik dan yang buruk. Dengan adanya ruh tersebut manusia bias mengetahui perbuatan baik apa saja yang harus dikerjakannya dan perbuatan buruk (jahat) apa saja yang harus dijauhi dan dihindarkan. Artinya, dengan adanya ruh manusia berpotensi menjadi makhluk yang baik dan sebagai pengemban amanat Tuhan di dunia, yakni sebagai hamba Tuhan yang hidupnya berorientasi kepada kebenaran dan kebaikan Tuhan (Nurwardani , 2016, hal. 31-32).

Pengalaman bertuhan (spiritual) bagi setiap orang berbeda-beda dan tidak ada yang persis sama. Setiap orang memiliki pengalaman yang khas dan unik dalam merasakan 
kehadiran Tuhan. Pengalaman tersebut biasanya sangat dipengaruhi faktor psikologis seseorang. Berbagai problematika dan kegaduhan kehidupan modern seperti saat ini yang lebih berorientasi kepada kehidupan individualistik dan materialistic, menjadikan nilainilai spiritualistik seolah-olah tidak mendapatkan tempat bagi setiap orang modern. Modernisasi di segala bidang kehidupan yang sejatinya mempermudah dan mendekatkan bagi setiap manusia justru membuat manusia itu menjadi sepi, merasa sendiri, dan terasing (teralienasi). Kondisi tersebut diperparah lagi dengan tidak adanya ketenangan dan kedamaian dalam diri manusia tersebut. Oleh karena itu, dalam konteks kehidupan modern seperti saat ini manusia harus kembali kepada jati dirinya, bahwa ada anugerah Tuhan yang sangat berharga pada dirinya yang harus dikembalikan fungsinya sebagaimana Tuhan menciptakannya dalam keadaan suci (fitrah). Untuk itu, yang harus dilakukan adalah mengasah dan mempertajam spiritualitas. Mengasah dan mempertajam spiritualitas tersebut sebagai salah satu upaya penguatan visi ilahiyah, potensi bertuhan atau berketuhanan. Yang juga merupakan proses pengaktualisasian akhlah Tuhan yang ada pada diri setiap manusia, takhallaqū fí khalqi al-Ih. Untuk mewujudkan hal tersebut diperlukan latihan jiwa secara sistematis, dramatis, dan berkesinambungan dengan memadukan beberapa unsur, dari olah fikir (tafakkur wa ta'ammul), olah rasa (tazawwuq), olah jiwa (riyāộh), dan olah raga (rihlah wa jihad).

Salah satu bentuk praktek ajaran tasawuf adalah membaca wirid. Tradisi membaca wirid biasanya dilakukan secara bersama-sama di kalangan komunitas pengamal tasawuf yang biasa disebut dengan kelompok tarekat (Arab: tariqah). Bagi kelompok tarekat biasanya ada amalan-amalan tertentu ataupun bacaan-bacaan tertentu yang diwajibkan (wazifah), baik bersifat harian, pekanan, maupun bulanan. Penelitian ini mencoba untuk mengelaborasi wirid harian dari kitab al-Aurād al-Nurāniyyah dengan cara mendeskripsikan, menginterpretasikan, dan menganalisis makna dalam teks-teks bacaan wirid tersebut, serta mencoba menghubungkan pengaruh dan relevansinya terhadap spiritualitas keberagamaan.

\section{Wirid Harian al-Aurād al-Nurāniyyah}

Kitab al-Aurād al-Nurāniyyah diterbitkan oleh kelompok majelis tarekat Shāziliyyah yang dipimpin oleh Syekh Muqbil 'Abd al-Rabb, seorang mufti dari Dubai, Uni Emirat Arab, yang memiliki sanad langsung dari gurunya sampai kepada Imam al- Shāziliyyah, pendiri tarekat Shäziliyyah. Tarekat Shaziliyyah adalah tarekat yang dipelopori oleh Syekh Abu al-Ḥasan Shāzilī. Nama Lengkapnya adalah Abū al-Ḥasan al-Shāzilî al- 
Ḥasanî bin 'Abd al-Lâh 'Abd al-Jabbār bin Tamīm bin Hurmuz bin Ḥātim bin Qushay bin Y ūsuf bin Yusha“ bin Ward bin Bațal bin Aḥmad bin Muḥammad bin Isa bin Muhammad bin Hasan bin 'Ali bin Abī Tạalib r.a dan Fạṭimah al-Zahra binti Rasulullah SAW (Gharib \& al-Shāzili, 2000, hal. 14). Kitab tersebut penulis dapatkan dari beliau langsung dan sudah mendapat izin dan legitimasi (ijäzah) untuk diamalkan dan diajarkan kepada orang lain.

Kitab tersebut berisikan amalan-amalan wirid yang terdiri dari wirid harian (alwird al-yaumī), ḩizb al-baḥr, amalan besar (al-wazifat al-kubrā), shalawat al-Yāqūtiyyah (al-shalāt al-Yāqūtiyyah), shalawat shăhib al-maqām, surat Yasin, dan doa mengharapkan cahaya (al-munājāt al-nürāniyyah). Semua wirid dan doa tersebut ada yang dibaca dan diamalkan harian maupun pekanan dan cara pembacaan juga harus sesuai dengan cara pembacaan yang diajarkan oleh syekh, sebagai pemilik sanad. Oleh karena itu, membaca dan mengamalkan wirid tersebut sebaiknya tidak sembarangan dan harus dituntun dan dibimbing oleh orang yang mendapatkan ijäzah. Untuk wirid harian dianjurkan membacanya setiap setelah shalat maghrib dan setelah shalat subuh.

Bacaan wirid harian dari kitab al-Aurād al-Nürāniyyah secara berurutan adalah sebagai berikut:

1) Membaca surat al-Fâtiḥah, dilanjutkan dengan membaca $Y \bar{a}$ Allāh, yā Rahmān, yā Rahìim, yā Rabb, yā Mālik (sebanyak 10 kali), kemudian mengulang sekali lagi dengan menyempurnakan potongan surat al-Fātihah dari ayat Māliki yaum al-dìn sampai akhir surat;

2) Membaca surat al-Wāqi'ah sampai akhir surat dan dilanjutkan dengan membaca ayat Q.s. al-Ṣāffāt/37:180-182;

3) Membaca ayat Q.s. al-Ahzab/33:56 yang dilanjutkan dengan membaca shalawat kamālāt sebanyak tiga kali dan diakhiri dengan membaca shalawat Qurubät sebanyak tiga kali. Adapun bacaan shalawat yang dimaksud adalah sebagai berikut:

$$
\begin{aligned}
& \text { اللهم صل و سلم بأنواع كمالاتك في جميع تجلياتك على سيدنا و مولانا محمد أول الأنوار الفائضيات من بحر }
\end{aligned}
$$

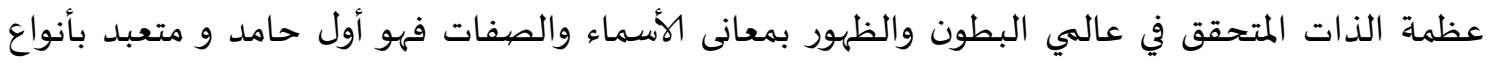

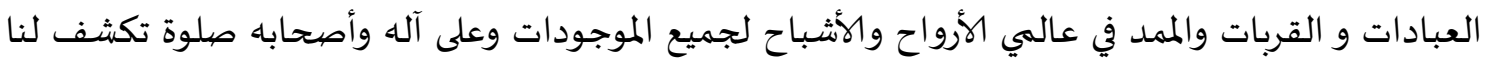

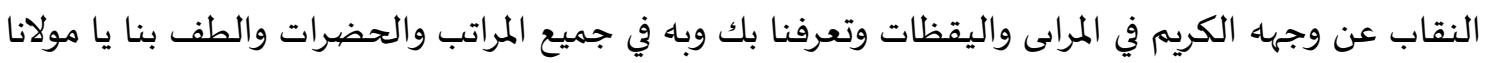

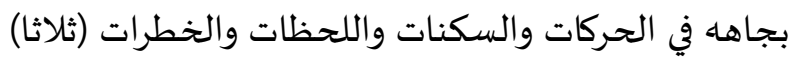

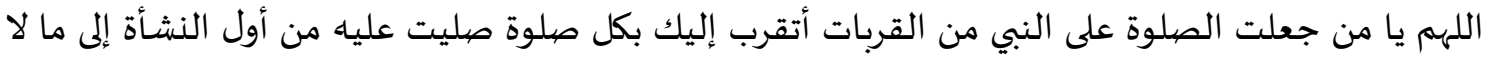

$$
\begin{aligned}
& \text { نهاية للكمالات (ثلاث) }
\end{aligned}
$$


4) Membaca ta'awwuz sekali, membaca basmalah tiga kali, kemudian membaca ayat Q.s. al-Muzammil/73:20, dan dilanjutkan dengan membaca istighfär sebanyak 99 kali, serta diakhiri dengan membaca istighfär yang lengkap;

أستخفر الله العظيم الذي لا إله إلأ هو الحي القيوم وأتوب إليه من كل ذنب جنيته على نفسي أو جررت إليه أحدا من خلقك

5) Membaca ayat Q.s. al-Ahzab/33:56 yang dilanjutkan dengan membaca shalawat kepada Nabi sebanyak 99 kali, seperti sebagai berikut:

$$
\text { اللهم صل على سيدنا محمد عبدك و رسولك النبي الأمي و على آله و صحبه و سلم }
$$

Kemudian diakhiri dengan membaca shalawat lengkap sebagai berikut:

اللهم صل على سيدنا محمد عبدك و رسولك النبي الأمي و على آله و صحبه و سلم تسليما و كن بنا و بالمؤمنين

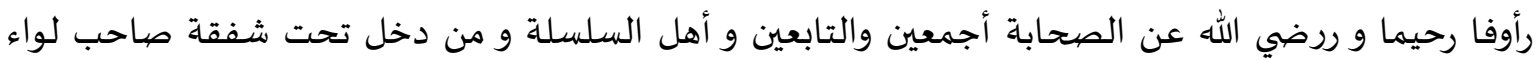

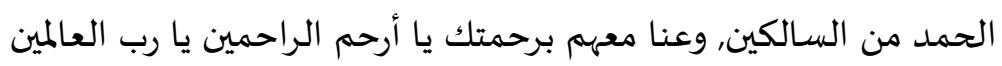

6) Membaca ayat Q.s. 'Āli 'Imrān/3:18-19 sampai ayat inna al-dīna 'inda al-Lāhi al-islām, lalu membaca berikut:

فاعلم أنه ( لا إله إلا الله - ثلاثا), سيدنا محمد رسول الله صلى الله وسلم علبه وعلى آله و أصحابه و أمته

Dilanjutkan dengan membaca tahlil lengkap sebanyak 99 kali seperti berikut:

$$
\text { والحاضرين }
$$

$$
\text { لا إله إلا الله وحده لا شريك لها, لله الملك وله الحمد يحيي ويميت بيده الخير وهو على كل شيئ قدير }
$$

Setelah itu ditutup dengan membaca tahऍil lengkap sebagai berikut:

لا إله إلا الله وحده لا شريك لها, له الملك وله الحمد يحيي ويميت بيده الخير وهو على كل شيئ قديروبالإجابة

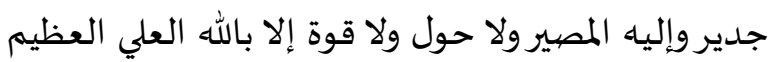

7) Membaca surat al-Ikhlās sebanyak tiga kali, kemudian membaca ayat Q.s. Ibrahim/14:7 dan potongan Q.s. al-Naml/27:59 disertai membaca doa Allahumma j’alnā minhum, kemudian dilanjutkan membaca hamdalah dan tashakkur ( الحمد الله sebanyak 99 kali, dan ditutup dengan membaca berikut:

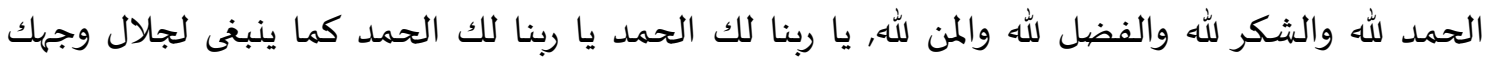

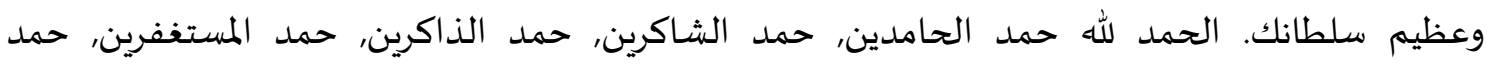
العارفين, حمدا يوافى نعمه ويدافع نقما ويكافئ مزيده

8) Membaca surat al-Ikhlās sebanyak tiga kali dan membaca surat al-Falaq, surat al-Nās, dan surat al-Fātiḥah masing-masing sekali, lalu membaca ayat Q.s. al-Shūrā/42:19, dan 
kemudian membaca: Yā lathif (يا لطيف) sebanyak 129 kali. Kemudian ditutup dengan doa sebagai berikut:

اللهم الطف بنا في قضائك, وعافنا من بلائك, واجعلنا من صفوة أوليائك

9) Membaca empat bagian doa yang di akhir dari masing-masing bagian doa tersebut dibacakan surat al-Fâtihah. Empat bagian doa tersebut terdiri dari: bagian pertama, agar dimasukkan ke dalam kelompok hamba yang selalu mendapatkan pengawasan berupa penglihatan dan pendengaran dari Allah swt. Bagian kedua, memohon kepada Allah melalui perantara para nabi, orang-orang yang șiddiq, para syuhada, dan orangorang saleh, supaya apabila bertemu dengan orang kafir semoga menjadi islām (patuh dengan ajaran Allah), mendapatkan kepastian dalam suatu urusan, orang yang sakit semoga disembuhkan, terhadap pelaku dosa agar diberi hidayah, dan atas segala persoalan dapat diselesaikan dengan baik. Bagian ketiga, semoga Allah memberkahi para wali Allah yang telah mengajarkan wirid ini secara turun temurun dan semoga wirid yang diajarkan tersebut memberi pencerahan (cahaya), tersingkap segala rahasia, keberkahan bagi orang-orang yang mengamalkannya. Dan bagian keempat, melalui kemulian surat al-Fātiḥah semoga segala perbuatan buruk yang kita lakukan menjadi kebaikan, segala kebaikan menjadi kesempurnaan, dan semoga Allah menempatkan kita dari maqām Islām kepada maqām mushāhadah (kesaksian) dan mata hati kita dapat mengungkap segala rahasia dan cahaya (surat al-Fātihah) melalui wirid-wirid yang kita baca tersebut. Empat bagian doa yang dimaksud adalah sebagai berikut:

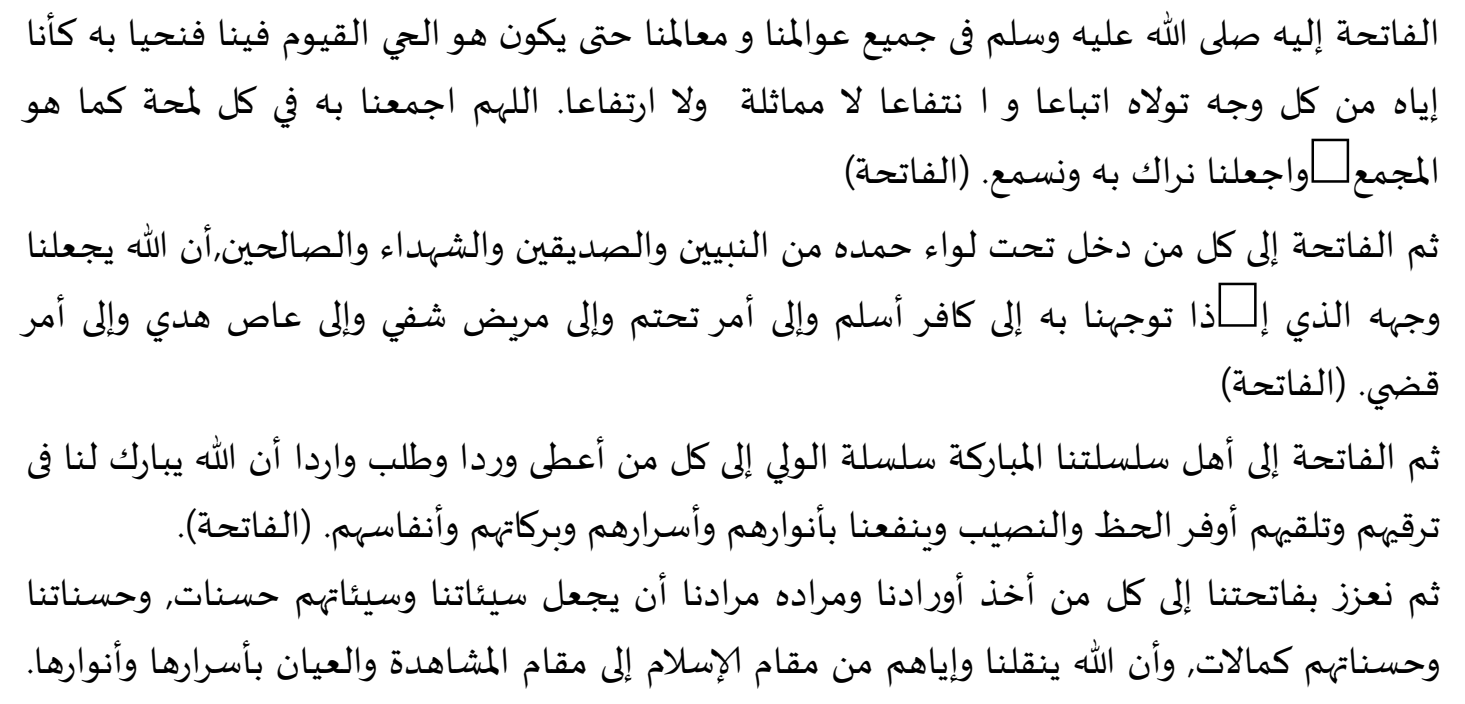


10) Terakhir, membaca tiga rangkaian shalawat yang masing-masing dibaca tiga kali. Tiga shalawat yang dimaksud adalah shalawat mahabbah, shalawat nubuwwah, dan shalawat risālah sebagaimana berikut:

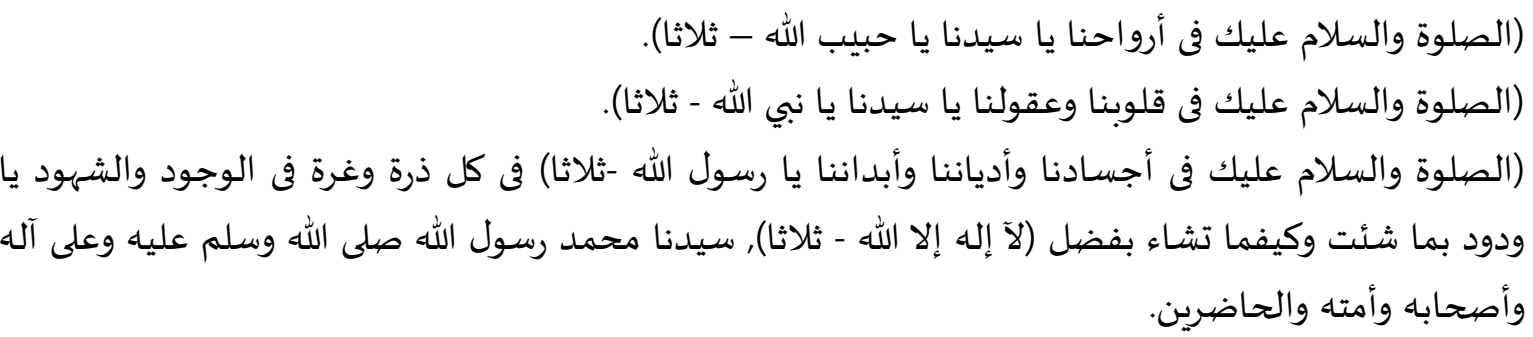

Dengan pembacaan shalawat tersebut di atas selesailah pembacaan wirid harian kitab alAurād al-Nürāniyyah.

Dari rangkaian bacaan wirid tersebut terdapat beberapa hal istilah penting yang dapat dielaborasi dan diteliti makna dan interpretasinya, seperti membaca surat alFâtihahah, membaca surat al-Wāqi’ah, membaca shalawat kepada Nabi Muhammad saw (dengan berbagai bentuk bacaan shalawat), membaca istighfär (memohon ampunan kepada Allah), membaca hamdalah dan tashakkur, membaca nama Allah latîf, dan membaca doa. Dari masing-masing istilah tersebut dijelaskan sebagaimana berikut.

1) Membaca surat al-Fātiḥah

Ada beberapa nama lain yang sama makna dengan surat al-Fātị̣ah. Pertama, disebut dengan Fātiḥah al-kitāb, karena pembuka mushaf, pengajaran dan bacaan dalam shalat. Kedua, disebut juga dengan surat al-Ḥamdu, karena ayatnya dimulai dengan alḩamdu. Ketiga, disebut juga dengan Umm al-kitāab, karena merupakan induk dari seluruh isi al-Qur'ān. Keempat, disebut juga dengan surat al-Sab' al-mașānī, karena terdiri dari tujuh ayat. Kelima, disebut juga al-Wăfiyah, karena membacanya harus sempurna sampai akhir, tidak boleh separuh-separuh. Keenam, disebut juga dengan surat al-Käfiyah, artinya mencukupkan. Ketujuh, disebut juga dengan al-Asās, karena menjadi dasar dari al-Qur'ān. Kedelapan, disebut juga dengan al-Syifä, karena menjadi obat bagi setiap penyakit. Kesembilan, disebut juga dengan al-Shalāt. Kesepuluh, disebut juga dengan surat al-Sūāl, karena ada ayat yang memohon petunjuk jalan lurus. Kesebelas, disebut surat al-Shukr, karena berisi pujian kepada Allah. Dan kedua belas, disebut surat al-Du'ā, karena berisi ayat permohonan (Fakhr al-Dīn bin 'Allāmah Diyā, 1981, hal. 179-183).

Menurut al-Alûsi ada empat puncak ilmu agama yang terkandung di dalam surat al-Fâtiḥah. Pertama, ilmu ushul atau ilmu aqidah ma'rifatullah (mengenal Allah) dan sifat-sifat-Nya (dipahami dari ayat Rabb al- 'ālamīn, al-rahmān al-rahim), ilmu nubuwwah 
(kenabian) (melalui ayat an'amta alaihim sampai akhir), dan hari akhir (seperti pada ayat maliki yaum al-dîn). Kedua, ilmu tentang ibadah (seperti pada ayat Iyyâka na'budu). Ketiga, ilmu akhlak dan ilmu suluk untuk mendekatkan diri kepada Allah (dipahami dari ayat iyyâka nasta'în. Ihdinâ al-shirâth al-mustaqîm). Dan keempat, ilmu tentang kisah, berita-berita tentang umat terdahulu yang menggambarkan kebahagiaan dan kesengsaraan dari janji baik maupun janji buruk (seperti tercermin pada ayat terakhir (Abu al-Faḍl Shihāb al-Dīn, xxvii, hal. 36).

Pada dasarnya, surat al-Fâtihah diturunkan Allah swt sebagai petunjuk awal bagi manusia dalam menjalani kehidupannya. Melalui bacaan basmalah Allah swt mengajarkan manusia bagaimana memulai setiap perbuatan ataupun pekerjaan yang dilakukannya. Allah swt juga mengajarkan bagaimana cara bersyukur dan memuji-Nya dengan bacaan ḥamdalah (Ibnu 'Așūr, 1984, hal. 11-12).

Manusia itu pada dasarnya terbagi kepada dua kelompok, yaitu kelompok yang memperoleh petunjuk dan kelompok yang sesat. Allah swt menganugerahkan kepada manusia lima bentuk hidayah (petunjuk) dalam upaya menggapai kebahagiaanya. Pertama, petunjuk inspirasi naluri (hidâyah ilhâm fitrî), yang sudah didapatkan sejak kelahirannya berupa merasakan kebutuhan untuk makan dan minum. Kedua, petunjuk indrawi (hidâyah hawâs) yang lebih sempurna dibandingkan dengan yang pertama. Ketiga, petunjuk akal (hidâyah 'aqlî), yang mampu membedakan yang hak dengan yang bathil. Keempat, petunjuk agama (hidâyah al-dîn), yang memberi jalan supaya manusia tidak salah dan tidak tersesat, karena kadang-kadang akal bisa salah akibat pengaruh dari dorongan hawa nafsu (Q.s. al-Balad/90:10). Kelima, petunjuk pertolongan kepada jalan kebaikan dan kesuksesan. Petunjuk ini lebih khusus dari sekedar petunjuk agama. Hal inilah yang selalu diharapkan oleh setiap manusia yang beriman melalui permohonannya: Ihdinâ al-shirât al-mustaqîm (Zuhaili al-, 2009, hal. 62-64).

2) Membaca surat al-Wâqi'ah

Surat al-Wâqi'ah merupakan salah satu yang sarat dengan fadhîlah (keutamaan) dan keberkahan. Surat tersebut adalah surat ke-56 dalam Al-Quran dan berisi 96 ayat. Salah satu keutamaan surat al-Wâqi'ah diketahui dari hadits yang diriwayatkan Abdullah bin Mas'ûd dan penjelasan para ulama mufassirin. Membaca surat al-Wâqi'ah tiap malam, insya Allah dijauhkan dari kemiskinan. Dalam riwayat tersebut dijelaskan bahwa Khalifah Utsman bin Affan bermaksud memberikan sejumlah harta kepada Abdullah bin Mas'ud untuk putra-putranya. Namun, Abdullah bin Mas'ûd menolak sembari menjelaskan bahwa 
dirinya sama sekali tidak khawatir putra-putranya menderita kemiskinan. Sahabat ahli tafsir itu pun membuka sebuah rahasia bahwa ia telah mengajarkan satu amalan yang pernah diajarkan Rasulullah kepadanya. “Apakah Amirul Mukminin takut putra-putraku miskin? Mereka sudah kusuruh membaca Surat Al Wāqiah setiap malam,” kata Abdullah bin Mas'ûd ketika sakit menjelang wafat. Ia kemudian menyampaikan sabda Rasulullah yang pernah didengarnya:

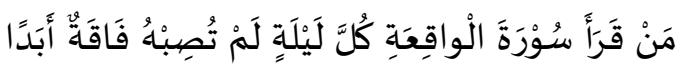
"Siapa yang membaca surat al-Wāqi'ah setiap malam, dia tidak akan menjadi miskin selama-lamanya” (HR. Abu Ya'lā dan Ibnu Asākir) (Abu al-Faḍl Shihāb al-Dīn, xxvii, hal. 128).

Ibnu Kasīr di dalam mengawali penafsirannya tentang surat al-Wāqi'ah mengatakan bahwa Abu Isḥ̄ạ mengatakan dari Ikrimah dari Ibnu Abbās berkata: Abū Bakar berkata,"Wahai Rasulullah saw tampak dirimu telah beruban.” Beliau bersabda, "Yang (membuatku) beruban adalah surat Hûd, al-Wāqi'ah, al Mursalāt, عما يتساءلون (An Naba', pen) dan إذا الشمس كورت." Diriwayatkan oleh Tirmidzi dan dia berkata: riwayat hadits ini adalah ḥasan gharīb (Kasīr \& Ismā'îl bin 'Umar al-Dim, 2000, hal. 1804).

3) Membaca shalawat atas Nabi Muhammad saw

Membaca shalawat merupakan salah satu ciri (bukti) kecintaan seseorang kepada Rasulullah saw, sebagaimana diperintahkan oleh pada Q.s. al-Aḥzāb/33:56. Shalawat memiliki beberapa makna. Jika shalawat tersebut berasal dari Allah, hal itu berarti anugerah rahmat. Jika berasal dari malaikat berarti memohonkan ampunan. Jika datang dari orang-orang beriman hal tersebut merupakan doa agar diberi rahmat.

Ada beberapa keutamaan yang dapat diraih bagi setiap orang yang selalu bershalawat kepada Rasulullah saw., di antaranya: dikabulkan setiap doanya, mendapat pahala yang berlipat ganda, diangkat derajatnya, dikumpulkan bersama Rasulullah saw di surge, dan akan mendapat safa'at (pertolongan) dari Rasulullah saw (Fakhr al-Dīn bin 'Allāmah Dịīā, 1981, hal. 228-229), (Zuhaili al-, 2009, hal. 421-424).

4) Membaca istighfär (memohon ampunan kepada Allah),

Memohon ampunan (istighfär) kepada Allah menunjukkan bahwa manusia itu adalah makhluk yang lemah dan selalu melakukan kesalahan ataupun kekhilafan, baik yang disengaja maupun yang tidak disengaja. Dengan istighfâr tersebut diharapkan segala dosa dan kesalahan yang telah dilakukan akan terhapus. Bahkan dalam beberapa riwayat dijelaskan bahwa orang- 
orang yang memohon ampunan dengan sungguh-sungguh dan bertekad tidak akan melakukan kesalahan lagi, dosanya diampuni seperti halnya seorang bayi yang baru dilahirkan.

Ada beberapa keutamaan dan manfaat yang dapat diraih bagi orang-orang yang memohon ampunan dari Allah swt. Pertama, sebagai penghapus dosa dan kesalahan, sebagaimana dijelaskan di dalam Q.s. al-Nisā/4:110. Kedua, mendapat jaminan tidak akan mendapat siksaan dari Allah swt, sebagaimana dijelaskan dalam Q.s. al-Anfâl/8:33. Ketiga, orang yang selalu beristighfar akan mendapat rezeki dan kenikmatan dari Allah, sebagaimana dijelaskan di dalam Q.s. Hūd/11:3. Hal inilah yang dilakukan oleh umat Nabi Nuh a.s. yang memohon ampunan ketika mereka durhaka, sebagaimana dinyatakan di dalam Q.s. Nūh/71:10-12. Keempat, memohon ampunan merupakan sifat dan perilaku dari para nabi dan rasul. Perhatikanlah bagaimana Nabi Adam a.s. memohon keampunan setelah beliau dan istrinya berbuat kesalahan (Q.s. al-A'rāf/7:23). Demikian pula halnya dengan Nabi Nūh a.s. (Q.s. Nūh/71:28), Nabi Misāa a.s. (Q.s. al-Qașaș/28:16), Nabi Dāwūd a.s. (Q.s. Șad/38:24), Nabi Sulaimān a.s. (Q.s. Șad/38:35). Rasulullah saw memohon ampunan kepada Allah seratus kali setiap harinya (Ibnu 'Așūr, 1984, hal. 289-290), (Zuhaili al-, 2009, hal. 229-230).

5) Membaca tahlil

Bacaan tahlîl yang diajarkan oleh Rasulullah saw adalah sebagai berikut

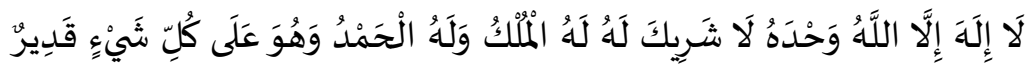

Ada empat keutamaan membaca tahlîl secara tertentu sebanyak seratus kali setiap hari, menurut Imam Ghazā̄i (Ghazāli, hal. 298-305) mengutip dari beberapa hadits dari Rasulullah saw. Pertama, orang yang membaca tahlîl, menurut Nabi, seperti halnya orang yang telah memerdekan sepuluh budak. Dengan demikian, kandungan dari bacaan tahlîl dapat dimaknai sebagai bentuk penghargaan dan penghormatan bagi kaum yang lemah, seperti halnya budak. Hal tersebut juga dapat dimaknai bacaan tahlil merupakan deklarasi atas kesamaan hak dan kewajiban bagi setiap manusia. Kedua, orang yang selalu membaca tahlîl akan mendapat seratus kebaikan. Ketiga, dihapuskan seratus kesalahan seseorang yang telah diperbuatnya. Kedua manfaat ini dapat diilustrasikan dengan ketika di hari kiamat semua amalan akan ditimbang antara berat kebaikan dan keburukannya (Q.s. al-Zalzalah/99:7-8). Bagi orang yang selalu membaca tahlîl, keburukan perbuatannya akan terbayarkan dengan seratus kebaikan dari pahala bacaan tahlîlnya. Keempat, akan selalu dilindungi dari gangguan setan selama sehari semalam.

6) Membaca Hamdalah dan Syukur

Membaca hamdalah biasanya diistilahkan dengan sebutan tahmîd, yaitu memuji Allah swt. Bacaan hamdalah merupakan bacaan lanjutan setelah membaca basmalah pada surat al-Fātiḥah. Hal tersebut memberikan makna sebagai bentuk penghormatan, pujian, 
dan ucapan terima kasih hamba kepada Tuhannya atas anugerah-Nya yang sangat besar kepada seluruh makhluk, tanpa membeda-bedakan apakah patuh atau durhaka maupun beriman atau ingkar, sebagaimana dipahami dari sifat rahmān Allah swt. Ataupun juga anugerah khusus yang diberikan Tuhan kepada hamba-hamba-Nya yang beriman dan patuh, sebagaimana dipahami dari sifat rahim Allah swt.

Kalimat ḥamdalah (al-ḥamdu li al-Läh) dalam al-Quran ditemukan sebanyak 24 kali dengan berbagai varian konteksnya ('Abd al-Bāqì, 1364 H, hal. 216). Sebelum membaca wirid hamdalah ini didahului dengan membaca potongan ayat Q.s. Ibrahim/14:7 dan potongan Q.s. al-Naml/27:59 disertai membaca doa Allahumma j'alnā minhum. Terkait dengan Q.s. al-Naml/27:59, al-Zamkhshari mengomentari ayat ini dengan mengutip perintah dari Nabi untuk selalu membaca ayat tersebut terutama di awal pembuka khutbah, karena disinyalir ayat tersebut berisikan unsur ketauhidan dan kekuasaan Allah swt. Di samping itu, ayat tersebut mengandung doa memohon keberkahan (tabarruk) bagi hamba-hamba pilihan Tuhan, baik dari kalangan nabi dan rasul maupun orang-orang shalih ('Allaāmah Jār al-Lāh `Abī Qāsim Ma, 1998, hal. 463)

7) Membaca Yà Latịif

Lathîf merupakan salah salah nama dan sifat Allah yang artinya Maha Lembut. Yà Latị̂f merupakan dzikir menyeru kepada Allah yang Maha Lembut. Menyeru nama Allah yang Maha Lembut merupakan bentuk permohonan kita kepada Allah supaya Allah melembutkan hati kita agar hati kita tidak tersesat dan selalu mengingat-Nya sehingga kita tidak termasuk sebagai orang-orang celaka (Q.s. al-Zumar/39:22). Hati merupakan pusat koordinasi dari seluruh anggota badan dalam mengerjakan sesuatu. Hati yang tunduk kepada Allah adalah hati yang selalu zuhud dari pesona kehidupan dunia dan selalu merindukan bertemu dengan Allah swt. Orang yang selalu menempatkan hatinya dengan mengingat Allah, pasti ia akan merasa tenang dan tentram (Q.s. al$\mathrm{Ra}$ 'd/13:28).

Hati adalah tempat bertumpu jiwa dan perasaan kita. Dengan membaca Yā Latịf kita memohon kepada Allah agar hati kita selalu dilembutkan dalam menerima qadha (ketentuan) dariNya, jiwa kita diselamatkan dari berbagai ujian dan cobaan (balāa), dan kita menjadi hamba Allah yang bersih hatinya.

8) Membaca doa

Secara kebahasaan (etimologis) perkataan doa berasal dari perkataan bahasa Arab $d u$ 'à yang artinya memohon atau meminta. Istilah doa juga seakar dengan perkataan dakwah (da'wah) yang artinya mengajak, mengundang atau menyeru. Dua istilah tersebut sudah menjadi kata serapan dalam bahasa Indonesia. Perbuatan berdoa dimaksudkan 
sebagai permohonan seorang hamba kepada Allah untuk mendapatkan jalan kebenaran dalam rangka menggapai kebaikan dan kesejahteraan bagi dirinya. Di sisi lain (Q.s. alBaqarah/2:186), Allah justru memerintahkan kepada hambanya untuk selalu meminta, karena Dia pasti menjawab seruan (doa) hamba-Nya kepada-Nya jika hamba-Nya mau memperkenankan segala perintah-Nya, beriman kepada-Nya agar mereka menemukan jalan hidup sejati (Q.s. al-Anfāil/8:24).

Berdoa sebenarnya bukan hanya sekedar meminta sesuatu yang bersifat materi semata, tetapi lebih dari itu berdoa merupakan cara seorang hamba untuk berkomunikasi dengan Tuhannya agar ia merasa lebih dekat (taqarrub), merasa diperhatikan dan diawasi, sehingga hamba tersebut tidak merasa sendiri (Q.s. al-Ḍhạā/93:3). Berdoa juga merupakan bentuk orientasi hidup manusia bahwa keberadaan dirinya, jalan dan nasib hidupnya, dan akhir dari kehidupannya itu adalah milik Tuhan (innā li al-lāhi wa innā ilaihi rāji'ùn). Oleh karena itu, dalam sebuah hadits Nabi dijelaskan bahwa doa adalah otak (pusat saraf) dalam beribadah (al-du'a'u mukhkh al- 'ibādah). Hal tersebut menunjukkan bahwa berdoa dalam artian memohon kepada Allah merupakan titik sentral kesadaran dalam berketuhanan.

Permohonan doa yang dibaca di dalam wirid harian tersebut tidak hanya untuk diri kita sendiri, tetapi juga kita mohonkan untuk orang lain, bahkan untuk semua manusia, terutama diperuntukkan bagi orang-orang yang memiliki masalah-masalah khusus, seperti terhadap orang kāfir (mengingkari Tuhan) semoga menjadi Islām (tunduk dan patuh kepada Tuhan), orang yang sedang sakit semoga disembuhkan, dan terhadap pelaku dosa pun kita mohonkan semoga dia bertaubat dan mendapat hidayah.

\section{Relevansi Wirid Harian Dalam Mengembangkan Spiritualitas Keberagamaan}

Secara sederhana spiritualitas dapat diartikan sebagai proses perjalanan kebatinan seseorang untuk mendekatkan dirinya dengan Tuhan Yang Maha Tinggi dengan melakukan latihan-latihan ruhani (riyāệyāt) dan menahan dari berbagai bentuk pengekangan diri yang akan memalingkan dirinya dari Tuhan. Perbuatan-perbuatan dilakukan semata-mata bertujuan untuk mencapai kebahagiaan abadi (Ruslan, 2008, hal. 16). Perwujudan dari spiritualitas tersebut pada hakikatnya menjadikan seseorang memiliki kesalahenan pribadi. Seperti dijelaskan di dalam Q.s. al-Shams/91:7-10 manusia pada dasarnya sudah diberi potensi (berupa nafs, dipinjam ke dalam bahasa Indonesia dengan artian jiwa) untuk mengembangkan spiritualitas tersebut. Dalam hal ini, Ibnu 
'Ashūr menjelaskan bahwa bentuk nakirah pada kata nafs menunjukkan keumuman makna yang mencakup keseluruhan pada diri manusia tersebut, bukan sekedar jiwanya saja. Seperti halnya proses penciptaan dan penyempurnaan manusia tidak ada yang berbeda antara satu dengan lainnya. Artinya, proses penyempurnaan bentuk manusia dari masa pembentukan janin, masa kanak-kanak hingga masa dewasanya mencakup kesempurnaan keseluruhan fisik, baik dari segi kemampuan motorik maupun intelektual (Ibnu 'Așūr, 1984, hal. 368).

Sejalan dengan pertumbuhan fisik pada diri manusia, Tuhan akhirnya memberikan ilhām kepada manusia, yaitu potensi untuk menangkap pesan-pesan ketuhanan (Q.s. alSyams/91:8). Menurut Ibnu Asyûr, perkataan ilhām sebelum kedatangan Islam tidak dikenal dalam tradisi Arab. Tidak ada informasi yang dapat dicari dari syair-syair Arab kuno terhadap istilah tersebut. Justru al-Quranlah mengenalkan istilah tersebut yang mengandung makna mendalam menyangkut kejiwaan. Masih menurut Ibnu Asyûr, kata ilhām berasal dari dari kata lahm yang berarti sekali tegukan. Di kalangan sufi, istilah ilham digunakan untuk menyatakan konsep keilmuan tertentu yang bermakna hadirnya pengetahuan manusia tanpa melalui proses belajar maupun penalaran. Dengan kata lain, ilham merupakan ilmu yang tidak berdasar dalil (petunjuk), yang keberadaannya seperti insting (naluri) pada manusia. Ilham inilah yang dapat memahami apa yang dimaksud dengan fujür (jahat) dan takwa dengan rinciannya. Demikian pula dengan perihal dosa dan pahal (Ibnu 'Așūr, 1984, hal. 368).

Berdasarkan argumentasi Ibnu Ashūr tersebut di atas, dapat dipahami bahwa sejatinya sejak dari awal penciptaan manusia, Tuhan sudah menganugerahkan berupa potensi "jiwa" dalam menentukan jalan kebaikan dengan jalan keburukan. Potensi inilah yang mengantarkan manusia untuk menemukan jalan kebertuhanan dan mendapatkan nilai-nilai kebenaran yang berasal dari Tuhan. Potensi ini pula yang dapat menjaga dan membentengi jiwa dari hal-hal negatif yang akan mengotori dan menjauhkan manusia dari Tuhannya. Apabila manusia sadar dan selalu memfungsikan jiwa ilham tersebut dengan selalu menyucikannya, maka sejatinya dia termasuk orang yang beruntung. Sebaliknya, apabila jiwa tersebut selalu dikotori dengan perbuatan yang dilarang Tuhan, maka manusia tersebut akan merugi dan mendapat kesengsaraan (Q.s. al-Shams/91:9-10).

Sebenarnya, menjaga memelihara jiwa agar dekat dengan Tuhan tidak lain adalah dengan cara selalu tunduk dan menjalani semua aturan Allah, baik berupa perintah yang harus dijalankan maupun larangan yang harus dihindari, dan selalu beribadah kepada-Nya. 
Hanya dengan cara inilah jiwa terbentuk menjadi pribadi yang tenang dan berbahagia, karena selalu berpegang teguh kepada kebenaran dan keadilan (Q.s. al-Fajr/89:27-30).

Di antara upaya untuk selalu mendekatkan diri kepada Allah dalam bentuk ibadah adalah dengan mengamalkan amalan-amalan wirid. Hal tersebut dimulai dengan bertekad untuk mengamalkan amalan wirid setiap hari dengan menjadikannya sebagai rutinitas (wazifah) harian. Rutinitas tersebut memang harus dilakukan agar menjadi kegiatan yang mendarah daging (taken for granted).

Sejalan dengan menjadikan amalan wirid sebagai rutinitas, perlu juga dikembangkan pemahaman makna terhadap amalan-amalan wirid tersebut, agar tidak terjebak kepada rutinitas formal semata. Sekalipun amalan tersebut sifatnya sangat sederhana, namun kalau tanpa diberikan pemahaman atas makna amalan tersebut, dikhawatirkan akan muncul kejenuhan dan kebosanan yang justru kontra produktif dengan maksud dan tujuan amalan wirid tersebut. Oleh karena itu, perlu diberikan pemahaman tentang muwäjahah (berinteraksi) dengan Tuhan sebagai tafsiran atas amalan-amalan wirid tersebut. Tema-tema lain yang mendukung untuk menggairahkan amalanamalan wirid perlu juga didalami, seperti pemahaman tentang iman, ihsan, tawădu', khushū', khuḍu ', atau lainnya yang bertujuan untuk menumbuhkembangkan sikap kerendahan hati.

Cara lain yang cukup efektif mengatasi kebosanan tersebut dapat dilakukan dengan mengamalkan wirid secara berjamaah, paling tidak seminggu sekali. Hal inilah yang biasa dilakukan oleh kelompok tarekat ( ahl al-tariqah) sebagai wadah dalam mengamalkan amalan wirid secara berjamaah. Di samping itu, manfaat lain dari organisasi jamaah ini dapat saling mengawasi (mengontrol) dan menumbuhkan semangat untuk meningkatkan amalan wirid tersebut.

Amalan-amalan wirid tersebut pada hakikatnya merupakan proses pembiasaan dalam pengalaman berketuhanan. Sejatinya setelah mengamalkan amalan wirid tersebut dapat memperteguh hati kita dalam menjalani kehidupan di dunia maupun dalam rangka mempersiapkan diri untuk kehidupan akhirat. Sikap keteguhan hati tersebut bermula karena adanya sikap percaya kepada Allah, selalu berbaik sangka (pandangan positif), dan memiliki harapan kepada-Nya. Di samping itu, sikap pasrah dan selalu berserah diri (tawakkul) kepadanya menjadi sandaran dalam menmpuh kehidupan ini (Q.s. Yunus/10:84). Sikap-sikap baik seperti yang dijelaskan di atas dapat menumbuhkan dan mengembangkan nilai-nilai harmoni (keselarasan dan keteraturan) dalam menjalani kehidupan bagi diri pengamal wirid dan diharapkan memberi pengaruh positif bagi orang-orang di sekitarnya.

\section{Kesimpulan}

Kitab al-Aurâd al-Nūrāniyyah merupakan kitab yang berisikan amalan-amalan rutin (wazifah) berupa bacaan-bacaan wirid, zikir, dan doa harian, pekanan maupun bulan di kalangan pengikut tarekat Shāzilliyyah. Bacaan-bacaan tersebut di atas kemudian 
setelah ditelaah, diinterpretasi, dan dianalisis dengan merujuk kepada kitab-kitab tafsir, hadits maupun kitab-kitab akhlak dan tasawuf, mengandung banyak keutamaan (fadiliah), kemanfaatan, dan pengaruhnya bagi setiap muslim yang membacanya. Pengaruh tersebut tidak hanya dirasakan oleh pembacanya, bahkan siapapun yang mendengar di sekelilingnya, karena kandungan bacaan tersebut mendoakan semua orang yang sedang menghadapi masalah apapun agar mendapat solusi (ijābah) dengan perantaraan bacaanbacaan shalawat kepada Nabi saw sebagai kekasih Allah, pembawa berita (nubuwwah), dan penyampai ajaran Allah (risālah). Melalui perantaraan shalawat dan salām tersebut diharapkan terciptanya kedamaian dan harmoni bagi setiap orang.

\section{DAFTAR PUSTAKA}

'Abd al-Bāqì, M. F. (1364 H). Al-Mu'jam al-Mufahras li 'Alfāzh al-Qur' ān al-Karìm. Kairo: Dār al-Kutub al-Mishriyyah.

'Allaāmah Jār al-Lāh `Abī Qāsim Ma, a. Z. (1998). Al-Kashshāf 'an Haqāi iq Ghawāmiḍ al-Tanzîl wa 'Uyūn al- 'Aqāwîl fî̀ Wujūh al-Ta'wỉl. Riyạ̣: Maktabah al-'Abîkān.

Abu al-Faḍl Shihāb al-Dīn, a.-'. A. (xxvii). Rụh al-Ma'ānì fí Tafsìr al-Qữān al-'Azhīm wa al-Sab’ al-Masānī. Beirut: Dār Ihyạa wa al-Turās al-'Arabì.

Al-Aurad Al-Nurāniyyah. (t.thn.).

Al-Qur'an al-Azhim. (t.thn.).

(1995). The Encyclopedia of Religion. In M. Eliade. New York: Simon dan Schuster.

Fakhr al-Dīn bin 'Allāmah Dịiā, M. R. (1981). Tafsìr al-Fakhr al-Rāzī. Beirut: Dār alFikr.

Gharib, M., \& al-Shāzili, A. a.-Ḥ. (2000). Hayātuhu, Taṣawwufuhu, Talāmīzuhū wa Aurāduh. Kairo: Dār Gharîb.

Ghazāili, A. (t.thn.). Ihyă Ulūm al-Dīn. Semarang: Karya Toha Putra.

Ibnu 'Așūr, S. M. (1984). Tafsìr al-Tahrịir wa al-Tanwïr. Tunis: al-Dār al-Tūnīisiyyah. Jaeliy al-, A.-S.-K. (1375 H). Insan al-Kāmil fi Ma’rifat Awāliri wa al-Awā'il (Jilid II ed.). Mesir: Syarikah Matba'ah Mustafa- Babil Halabi wa Alādih.

Kasīr, I., \& Ismā'îl bin 'Umar al-Dim, A. a.-F. (2000). Tafsìr al-Qữān al-'Ażìm. Beirut: Dār Ibnu Hazm.

Madjid, N. (1995). Islam Agama Peradaban, Membangun Makna dan Relevansi Doktrin Islam Dalam Sejarah. Jakarta: Yayasan Paramadina. 
Nurwardani , P. (2016). Pendidikan Agama Islam Untuk Perguruan Tinggi. Jakarta: Direktorat Jenderal Pembelajaran dan Kemahasiswaan Kemenristekdikti.

Ruslan, H. (2008). Menyingkap Rahasia Spiritualitas Ibnu 'Arabi (Cet. I. ed.). Makassar: Al-Zikra.

Suyūthī al-, J. a.-D. (2003). Al-Durr al-Mansūr fî al-Tafsìr bi al-Măsūr. Kairo: Markaz Hijr li al-Buhūs wa al-Dirāsāt wa al-Islām.

Zamkhsyarî al-, '.-L. (1998). Al-Kasysyâf' 'an Haqâ’ iq Ghawâmidh al-Tanzîl wa 'Uyûn al‘Aqâwîl fî Wujûh al-Ta'wîl. Riyadh: Maktabah al-'Abîkân.

Zuhaili al-, W. (2009). al-Tafsir al-Munïr fî̀ al- 'Aqīdah wa al-Sharì'ah wa al-Manhaj (Cet. X ed.). Damaskus: Dār al-Fikr. 